\title{
GE11 Peptide-Installed Chimaeric Polymersomes Tailor-Made for High-Efficiency EGFR-Targeted Protein Therapy of Orthotopic Hepatocellular Carcinoma
}

\author{
Citation for published version (APA): \\ Zhou, C., Xia, Y., Wei, Y., Cheng, L., Wei, J., Guo, B., Meng, F., Cao, S., van Hest, J. C. M., \& Zhong, Z. (2020). \\ GE11 Peptide-Installed Chimaeric Polymersomes Tailor-Made for High-Efficiency EGFR-Targeted Protein \\ Therapy of Orthotopic Hepatocellular Carcinoma. Acta Biomaterialia, 113, 512-521. \\ https://doi.org/10.1016/j.actbio.2020.06.020
}

\section{Document license: \\ TAVERNE}

DOI:

10.1016/j.actbio.2020.06.020

Document status and date:

Published: 01/09/2020

\section{Document Version:}

Publisher's PDF, also known as Version of Record (includes final page, issue and volume numbers)

\section{Please check the document version of this publication:}

- A submitted manuscript is the version of the article upon submission and before peer-review. There can be important differences between the submitted version and the official published version of record. People interested in the research are advised to contact the author for the final version of the publication, or visit the $\mathrm{DOI}$ to the publisher's website.

- The final author version and the galley proof are versions of the publication after peer review.

- The final published version features the final layout of the paper including the volume, issue and page numbers.

Link to publication

\footnotetext{
General rights

- You may freely distribute the URL identifying the publication in the public portal. follow below link for the End User Agreement:

www.tue.nl/taverne

\section{Take down policy}

If you believe that this document breaches copyright please contact us at:

openaccess@tue.nl

providing details and we will investigate your claim.
}

Copyright and moral rights for the publications made accessible in the public portal are retained by the authors and/or other copyright owners and it is a condition of accessing publications that users recognise and abide by the legal requirements associated with these rights.

- Users may download and print one copy of any publication from the public portal for the purpose of private study or research.

- You may not further distribute the material or use it for any profit-making activity or commercial gain

If the publication is distributed under the terms of Article $25 \mathrm{fa}$ of the Dutch Copyright Act, indicated by the "Taverne" license above, please 
Full length article

\title{
GE11 peptide-installed chimaeric polymersomes tailor-made for high-efficiency EGFR-targeted protein therapy of orthotopic hepatocellular carcinoma
}

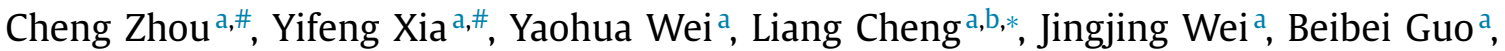 \\ Fenghua Meng ${ }^{\mathrm{a}, *}$, Shoupeng Cao ${ }^{\mathrm{c}}$, Jan C.M. van Hest ${ }^{\mathrm{c}}$, Zhiyuan Zhong ${ }^{\mathrm{a}, *}$ \\ a Biomedical Polymers Laboratory, College of Chemistry, Chemical Engineering and Materials Science, and State Key Laboratory of Radiation Medicine and \\ Protection, Soochow University, Soochow University, Suzhou, 215123, PR China \\ ${ }^{\mathrm{b}}$ Department of Pharmaceutics, College of Pharmaceutical Sciences, Soochow University, Suzhou, 215123, PR China \\ ${ }^{c}$ Eindhoven University of Technology, P.O. Box 513 (STO 3.31), 5600MB Eindhoven, the Netherlands
}

\section{A R T I C L E I N F O}

\section{Article history:}

Received 23 March 2020

Revised 25 May 2020

Accepted 11 June 2020

Available online 18 June 2020

\section{Keywords:}

Polymersomes

Protein delivery

Liver cancer

Active targeting

EGFR

\begin{abstract}
A B S T R A C T
Hepatocellular carcinoma (HCC) remains a leading malignancy with a high mortality and little improvement in treatments. Protein drugs though known for their extraordinary potency and specificity have rarely been investigated for HCC therapy owing to lack of appropriate delivery systems. Here, we designed GE11 peptide-installed chimaeric polymersomes (GE11-CPs) for high-efficiency EGFR-targeted protein therapy of orthotopic SMMC-7721 HCC-bearing nude mice. GE11-CPs were assembled from poly(ethylene glycol)- $b$-poly(trimethylene carbonate-co-dithiolane trimethylene carbonate)- $b$-poly(aspartic acid) (PEGP(TMC-DTC)-PAsp) and GE11-functionalized PEG-P(TMC-DTC), which allowed efficient loading and protection of proteins in the watery interior and fine-tuning of GE11 densities at the surface. CPs with short PAsp segments (degree of polymerization (DP) $=5,10$ and 15) exhibited a protein loading efficiency of 60\%-72\% and glutathione-responsive protein release. Saporin-loaded GE11-CPs had a size of $36-62 \mathrm{~nm}$ depending on GE11 densities and DP of PAsp. Notably, GE11-CPs with 10\% GE11 revealed greatly enhanced uptake in SMMC-7721 cells, boosting the anticancer potency of saporin for over 3-folds compared with non-targeted control (half-maximal inhibitory concentration $\left(\mathrm{IC}_{50}\right)=11.0$ versus $36.3 \mathrm{nM}$ ). The biodistribution studies using Cy5-labeled cytochrome $\mathrm{C}$ as a model protein demonstrated about 3-fold higher accumulation of GE11-CPs formulation than CPs counterpart in both subcutaneous and orthotopic SMMC7721 tumor models. Notably, saporin-loaded GE11-CPs revealed low toxicity, effective tumor inhibition and significant improvement of survival rate compared with PBS and non-targeted groups (median survival time: 99 versus 37 and 42 days). EGFR-targeted chimaeric polymersomes carrying proteins appear an interesting HCC treatment modality.
\end{abstract}

(c) 2020 Acta Materialia Inc. Published by Elsevier Ltd. All rights reserved.

\section{Introduction}

Hepatocellular carcinoma (HCC) remains one of leading malignancies worldwide with a high mortality and recurrence rate [1]. The major treatments include surgery, interventional therapy (such as transcatheter arterial chemoembolization), chemotherapy, radiotherapy, and recently developed targeted therapy and immune therapy [2]. For instance, sorafenib (Nexavar), a multi-kinase inhibitor, was approved by FDA in 2007 as a first-line treatment

\footnotetext{
* Corresponding authors.

E-mail addresses: chengliang1983@suda.edu.cn (L. Cheng), fhmeng@suda.edu.cn (F. Meng), zyzhong@suda.edu.cn (Z. Zhong).

\# These authors contribute equally to this work.
}

of inoperable or distantly metastatic primary HCC; however, sorafenib is associated with systemic side effects and drug resistance [3]. Navobizumab (PD-1 antibody) approved in 2018 for advanced liver cancers, nevertheless, could only benefit ca. $25 \%$ patients due to the insufficient PD-L1 expression [4]. Developing new modality for HCC treatment is thus highly desired. Active targeting nanomedicines are particularly promising for HCC treatment as selective drug delivery would not only increase drug accumulation in the tumor and uptake by HCC cells but also spare the healthy liver cells, thus boosting efficacy and reducing side-effects [5-7]. In the past years, a range of targeted nanomedicines were designed and prepared by decorating with specific ligands like transferrin [8], anti-glypican-3 antibody [9] anti-CD44 antibody [10], anti-EGFR antibody [11], GE11 peptides [12], SP94 peptide [13] and 
galactose [14]. Notably, reported HCC-targeted nanomedicines are mostly based on classical cytotoxic small molecule drugs such as docetaxel (DTX) and doxorubicin (DOX) that would cause adverse effects when leaked out during circulation and in the healthy organs. In this regard, biopharmaceuticals such as proteins [15,16] and nucleic acids [17] are advantageous and have appeared as next generation drugs in that they possess high activity and specificity, and cause little cytotoxicity when released in circulation and in the extracellular surroundings of non-targeted sites. On the other hand, vehicles play a decisive role for the applications of these biopharmaceuticals [18,19]. Huang et al. reported that galactose-functionalized nanoparticles efficiently delivered siRNA to HCC [20], and Zhu et al. fabricated RGDfC-functionalized selenium nanoparticles that could transport HES5-siRNA to HepG2 cells and achieve a significant improvement in silencing HES5 gene and growth inhibition of HepG2 cells in vitro and in vivo, while posed no toxicity to the mice [21]. Yin et al. reported galactose functionalized micelles loaded with DOX and Bcl2 siRNA that worked synergistically against the growth of subcutaneous and orthotopic HCC tumors [22]. Notably, there is no report on targeted nanomedicines based on protein drugs for HCC therapy.

In contrast to chemical drugs, proteins are big, fragile, easily denatured by organic solvents, and quickly degraded by proteinases, which pose far greater challenges on their delivery $[23,24]$. Vehicles like liposomes, nanogels, and polymersomes have recently appeared interesting for targeted intracellular protein delivery [2527]. Among the antitumor proteins, protein toxin saporin (Sap) is unique in terms of potency, stability, availability, and cost. Several antibody-Sap conjugates (immunotoxins) were investigated for treating acute lymphoblastic leukemia, lymphoma and melanoma [28-30], and BU12-saporin, an anti-CD19 immunotoxin was advanced in phase I clinical trial for B-cell tumors [31]. Sap is a single-stranded ribosome inactivating protein (RIP) showing remarkable potency with a half-maximal inhibitory concentration $\left(\mathrm{IC}_{50}\right)$ in the nano molar $(\mathrm{nM})$ range but only when entered the cells due to the lack of beta chain responsible for inserting into the cell membranes [32]. These immunotoxins, however, are associated with potential immunogenicity and safety concerns [33,34]. To deal with these problems, Sap was encapsulated into nanocarriers and delivered to breast tumor cells in vivo $[35,36]$. We recently found that glioma-targeting peptidefunctionalized chimaeric polymersomes based on biodegradable poly(ethylene glycol)-b-poly(trimethylene carbonate-co-dithiolane trimethylene carbonate)- $b$-polyethylenimine (PEG-P(TMC-DTC)-PEI) triblock copolymer could encapsulate and deliver Sap to glioblastoma, resulting in high-efficiency protein treatment [37]. However, cationic PEI is not the optimal polymer to interact with Sap in that Sap with a $\mathrm{pI}$ of ca. 11 has also a net positive charge at neutral $\mathrm{pH}$, and PEI might cause toxic concerns. We anticipated that using a polyanion to replace PEI might increase the loading content and efficiency toward Sap, reduce the size of protein nanoformulations, and enhance their stability, in addition to eliminate potential toxicity.

Here, we report the development of GE11 peptide-installed chimaeric polymersomes with negatively charged inner shell (GE11CPs) from PEG-P(TMC-DTC)-poly(aspartic acid) (PEG-P(TMC-DTC)PAsp) and GE11 peptide-functionalized PEG-P(TMC-DTC) for highefficiency EGFR-targeted protein therapy of orthotopic SMMC-7721 HCC in nude mice. EGFR is known highly expressed in a majority of HCC patients [38]. The overexpression of EGFR was found to correlate with the aggressiveness and metastatic status of human HCC $[39,40]$. GE11 is 11-mer peptide that has shown a high affinity and specificity to EGFR [41]. GE11-decorated nanomedicines were investigated for targeted treatment of different EGFR-positive tumor models [42-44]. The influence of PAsp length and GE11 density on loading of Sap and EGFR-targeting ability, respectively, was investi- gated. The in vivo studies revealed significant tumor inhibition and survival benefits with little toxic effects in orthotopic SMMC-7721 HCC-bearing mice at a dose of $25 \mathrm{nmol} \mathrm{Sap} / \mathrm{kg}$.

\section{Experimental section}

\subsection{Synthesis of PEG-P(TMC-DTC)-PAsp}

PEG-P(TMC-DTC) block copolymer with an $M_{\mathrm{n}}$ of $5.0-14.6-$ $2.1 \mathrm{~kg} / \mathrm{mol}$ and $p$-nitrophenyl chloroformate (NPC) activated copolymer PEG-P(TMC-DTC)-NPC were synthesized as previously reported [45]. First, under nitrogen environment into a stirred solution of $4 \mathrm{~mL}$ anhydrous DMSO containing $45.4 \mu \mathrm{mol}$ polyaspartic acid (KDn, $n=5,10$ or 15$)$ and $130 \mu \mathrm{L}$ triethylamine $(0.944 \mathrm{mmol})$ in a two-neck bottle, PEG-P(TMC-DTC)-NPC (500 mg, $22.7 \mu \mathrm{mol})$ in $1 \mathrm{~mL}$ anhydrous DMSO was dropwise added in a time course of $30 \mathrm{~min}$ at $4{ }^{\circ} \mathrm{C}$. After $48 \mathrm{~h}$ reaction at $25{ }^{\circ} \mathrm{C}$, the solution was dialyzed (MWCO $7000 \mathrm{Da}$ ) against DMSO for $18 \mathrm{~h}$ (5 times exchange of medium) and DCM for $6 \mathrm{~h}$ (twice exchange of medium). Then the solution was concentrated via rotary evaporator to ca. 100$150 \mathrm{mg} / \mathrm{mL}$, and PEG-P(TMC-DTC)-PAsp was finally recovered by precipitation in cold diethyl ether and vacuum dry. Yield: 95\%. The functionality of PAsp was characterized by ${ }^{1} \mathrm{H}$ NMR and TNBSA assays. PEG-P(TMC-DTC)-PAsp with KD5, KD10 and KD15 were synthesized with good functionality of ca. $95 \%, 92 \%$ and $88 \%$, respectively.

\subsection{Preparation and characterization of empty GE11-CPS}

Blank GE11-CPs were acquired via adding $25 \mu \mathrm{L}$ DMSO solution of GE11-PEG-P(TMC-DTC) and PEG-P(TMC-DTC)-PAsp mixture $(40 \mathrm{mg} / \mathrm{mL}$ ) at predetermined ratios (GE11 molar content of $10 \%$, $20 \%$, or $30 \%$ ) to $0.975 \mathrm{~mL}$ of HEPES buffer ( $\mathrm{pH} 6.8,5 \mathrm{mM}$ ) under mild stirring for 3 min followed by standing still for $0.5 \mathrm{~h}$ at $25{ }^{\circ} \mathrm{C}$ and dialysis against phosphate buffer ( $\mathrm{PB}, \mathrm{pH} 7.4,10 \mathrm{mM}$ ) for $3 \mathrm{~h}$ (MWCO $1000 \mathrm{kDa}$ ). Blank CPs were obtained in a similar way but without GE11-PEG-P(TMC-DTC). The size distribution and zeta potential were measured using respective dynamic light scattering (DLS) and electrophoresis. The morphology was studied using Cryo-TEM. The stability of GE11-CPs against dilution, 10\% fetal bovine serum (FBS) solution, and storage at $4{ }^{\circ} \mathrm{C}$ was studied by DLS.

\subsection{The loading and in vitro release of proteins}

The protein-loaded GE11-CPs and CPs were acquired as described above except that HEPES buffer ( $\mathrm{pH} 6.8,5 \mathrm{mM}$ ) containing saporin (Sap) or Cy5-labeled cytochrome C (Cy5-CC) were used during the assembly. The size, size distribution, zeta potential, and stability of Cy5-CC-GE11-CPs, Cy5-CC-CPs, Sap-GE11-CPs, and Sap-CPs were determined as above description for blank polymersomes. The protein loading content and efficiency were determined using BCA assays.

The in vitro protein release from protein-loaded polymersomes was studied by dialyzing $0.5 \mathrm{~mL}$ Cy5-CC-GE11-CPs $(0.5 \mathrm{mg} / \mathrm{mL})$ in $25 \mathrm{~mL} \mathrm{~PB}(\mathrm{pH} 7.4,50 \mathrm{mM})$ with or without $10 \mathrm{mM}$ glutathione (GSH) under constant stirring (MWCO $300 \mathrm{kDa}$ ). At predetermined time intervals, $5 \mathrm{~mL}$ of dialysis medium was taken and freeze-dried for quantification of protein, and $5 \mathrm{~mL}$ fresh medium was supplemented. The protein released and that remained in the polymersomes were measured by fluorescence spectroscope (Ex $645 \mathrm{~nm}$, Em. 650-750 nm). The release experiments were conducted in triplicate. 


\subsection{Saporin activity in inhibiting protein synthesis}

SMMC-7721 cells following seeding in a 6-well plate $(1.8 \mathrm{ml}$, $2 \times 10^{5}$ cells/well) overnight were incubated with free Sap, SapCPs/KD5, or Sap-10GE11-CPs/KD5 (Sap: $20 \mathrm{nM}$ ) for $4 \mathrm{~h}$ and then cultured in $2 \mathrm{~mL}$ fresh medium for $24 \mathrm{~h}$ or $48 \mathrm{~h}$. The cells were digested, centrifuged $(1000 \times \mathrm{g}, 3 \mathrm{~min})$, and washed with cold PBS $(\times 2) .60 \mu \mathrm{L}$ cell lysis buffer was added and the mixture was shaken for $0.5 \mathrm{~h}\left(4{ }^{\circ} \mathrm{C}, 200 \mathrm{rpm}\right)$ before centrifugation $(15,000 \times \mathrm{g}$, $20 \mathrm{~min})$ to remove cell debris. The protein contents in the supernatant were determined by BCA assays. As a control, SMMC-7721 cells were pretreated by 20 -fold excess of free GE11 peptide before adding Sap-10GE11-CPs/KD5.

\subsection{MTT assays}

The influence of GE11 surface contents on the antitumor activity was studied using Sap-GE11-CPs with KD5 at Sap concentrations ranging from 0.003 to $120 \mathrm{nM}$. The SMMC-7721 cells were seeded in 96 -well plates $\left(3 \times 10^{3}\right.$ cells/well $)$ in an atmosphere containing $5 \% \mathrm{CO}_{2}$ at $37{ }^{\circ} \mathrm{C}$ for 16 h. $20 \mu \mathrm{L}$ of Sap-GE11$\mathrm{CPs} / \mathrm{KD} 5$ was added. After $4 \mathrm{~h}$ incubation, the media was removed and supplemented with $100 \mu \mathrm{L}$ fresh media. The cells were cultured for additional $44 \mathrm{~h}$ before adding $10 \mu \mathrm{L}$ PBS solution of 3(4,5-dimethylthiazol-2-yl)-2,5diphenyl-tetrazolium bromide (MTT) $(5.0 \mathrm{mg} / \mathrm{mL}$ ). After $4 \mathrm{~h}$, the supernatant was aspirated, and $150 \mu \mathrm{L}$ DMSO was added to dissolve MTT-formazan generated by live cells for $10 \mathrm{~min}$. The absorbance at $570 \mathrm{~nm}$ was measured using a microplate reader, and the cell viability (\%) was obtained by comparing with the absorbance of PBS treated cells (100\%). Data are presented as average \pm SD $(n=6)$. To block the EGFR, SMMC-7721 cells were incubated with 20 -fold excess of free GE11 peptide before adding Sap-10GE11-CPs/KD5.

The effect of PAsp length (i.e. KD5, KD10 or KD15) on the antitumor activity was studied using Sap-10GE11-CPs. The cytotoxicity of free Sap (6.25 to $200 \mathrm{nM}$ ) and empty 10GE11-CPs/KD5 (0.1 to $0.8 \mathrm{mg} / \mathrm{mL}$ ) were also determined.

\subsection{Cellular uptake studies}

For flow cytometry analysis, SMMC-7721 cells following seeding overnight in a 6 -well plate $\left(2 \mathrm{~mL}, 5 \times 10^{5}\right.$ cells/well $)$ were incubated with Cy5-CC-10GE11-CPs/KD5, Cy5-CC-20GE11-CPs/KD5 or Cy5-CC-CPs/KD5 (Cy5: $1 \mu \mathrm{M}$ ) for $4 \mathrm{~h}$. The cells were digested, centrifuged $(1000 \times g, 3 \mathrm{~min})$, washed with $\mathrm{PBS}(\times 2)$, re-suspended in $500 \mu \mathrm{L}$ PBS, and analyzed immediately using a BD FACS Calibur flow cytometer based on 10,000 cells. EGFR low-expressing K562 cells were used as control.

For CLSM studies, SMMC-7721 cells following seeding overnight on cover glass in 24 -well plates $\left(1.8 \mathrm{~mL}, 8 \times 10^{4}\right.$ cells/well $)$ were incubated with Cy5-CC-10GE11-CPs/KD5, Cy5-CC-20GE11CPs/KD5 or Cy5-CC-CPs/KD5 (Cy5: $5.89 \mu \mathrm{M})$ for $4 \mathrm{~h}$. The cells were washed with PBS $(\times 3)$ and fixed by adding $200 \mu \mathrm{L}$ of $4 \%$ paraformaldehyde solution for $15 \mathrm{~min}$ before staining with phalloidin-tetramethyl-rhodamine B $(10 \mu \mathrm{g} / \mathrm{mL}, 200 \mu \mathrm{L})$ for $80 \mathrm{~min}$ and with DAPI $(10 \mathrm{ug} / \mathrm{mL}, 200 \mu \mathrm{L}$ ) for $5 \mathrm{~min}$ (each step followed with PBS washing), and CLSM imaging (TCS SP5, Leica).

For both studies, to perform the inhibition experiments, free GE11 peptide (20-fold excess) was used to pretreat SMMC-7721 cells before adding Cy5-CC-10GE11-CPs/KD5 or Cy5-CC-20GE11CPs/KD5.

\subsection{In vivo pharmacokinetics}

For in vivo pharmacokinetic studies, Cy5-CC-10GE11-CPs with KD5, KD10 and KD15, Cy5-CC-20GE11-CPs/KD5, Cy5-CC-CPs/KD5 and free Cy5-CC (0.72 $\mu \mathrm{mol}$ Cy5 equiv. $/ \mathrm{kg})$ in $200 \mu \mathrm{L}$ PB were injected into female Balb/c nude mice via the tail veins $(n=3)$. At predetermined time points, $\sim 30 \mu \mathrm{L}$ blood was collected from the retro-orbital sinus of mice into heparinized tubes and immediately centrifuged. The plasma was then incubated for $24 \mathrm{~h}$ with $1 \mathrm{~mL}$ DMSO containing $20 \mathrm{mM}$ DTT in a shaking bath $\left(37^{\circ} \mathrm{C}, 200 \mathrm{rpm}\right)$. After centrifugation, Cy5-CC concentration in the supernatant was quantified using fluorometry and plotted as a function of time. The elimination half-lives and the area under the curve were derived.

\subsection{Establishment of subcutaneous and orthotopic liver tumor models in mice}

To establish subcutaneous liver tumor model, SMMC-7721 cells ( $3 \times 10^{6}$ cells per mouse) in $50 \mu \mathrm{L}$ PBS mixed with $30 \%$ BD Matrigel were subcutaneously injected into the right hind leg of female Balb/c nude mice (5 weeks). After ca. 14 days post inoculation, the tumor grew to $150-200 \mathrm{~mm}^{3}$. The tumor was measured using a caliper and volume was calculated from the formula $V=\left(L \times \mathrm{W}^{2}\right) / 2$, where $\mathrm{L}$ and $\mathrm{W}$ are the length and width of the tumor, respectively. These mice were used for in vivo imaging and biodistribution studies.

To establish orthotopic liver tumor model, SMMC-7721 cells $\left(3 \times 10^{6}\right.$ cells per mouse) in $50 \mu \mathrm{L}$ PBS mixed with $30 \%$ BD Matrigel were slowly injected into the right upper lobe of female Balb/c nude mice ( 5 weeks). The day of tumor inoculation was designated as day 0 . The tumor progression was tracked by measuring the plasma concentration of AFP and GP-73, and observing the tumors in excised livers as well as ascites development. On day $-2,7$, $10,14,18,30$ and 40, the plasma concentrations of AFP and GP-73 were detected by Elisa kits. On day 14, 18, 30, and 40, one mouse was sacrificed to observe the growth of primary liver tumors and the metastasis.

\subsection{The in vivo imaging and biodistribution of Cy5-CC-GE11-CPS}

On day 30 post-inoculation of SMMC-7721 cells subcutaneously or orthotopically, Cy5-CC-GE11-CPs/KD5 and Cy5-CC-CPs/KD5 $(0.72 \mu \mathrm{mol}$ Cy5 equiv. $/ \mathrm{kg})$ in $200 \mu \mathrm{L}$ PB were intravenously injected via the tail veins $(n=3)$. IVIS Lumina II system was used to track Cy5-CC distribution in major organs and tumors of the mice at $4,6,8$, and $10 \mathrm{~h}$. After $10 \mathrm{~h}$, the mice were sacrificed, and the heart, liver, spleen, lung, kidneys, and tumors were excised, washed, and weighed. The subcutaneous tumors and liver were sliced and stained with DAPI before CLSM observation.

For quantification of the biodistribution, the tumors and major organ tissues (ca. $0.1 \mathrm{~g}$ ) were separately homogenized in $0.6 \mathrm{~mL}$ of $1 \%$ Triton $\mathrm{X}-10$, and $0.9 \mathrm{~mL}$ of DMSO containing $20 \mathrm{mM}$ DTT was added to extract Cy5-CC for $24 \mathrm{~h}$ in a shaking bath $\left(37^{\circ} \mathrm{C}\right.$, $200 \mathrm{rpm})$. After centrifugation (12,000 rpm, $3 \mathrm{~min}), \mathrm{Cy} 5-\mathrm{CC}$ in the supernatant was measured using fluorometry and expressed as injected dose per gram of tissue (\%ID/g).

\subsection{In vivo antitumor efficacy in orthotopic liver tumor bearing mice}

The day of orthotopic inoculation of SMMC-7721 cells was designated day 0 . On day 12 , the mice were randomly divided into six groups $(n=6)$, and treated with different formulations once every four days until day 40 under two regimens. In regimen 1, Sap10GE11-CPs/KD5 and Sap-20GE11-CPs/KD5 were given at $12.5 \mathrm{nmol}$ Sap/kg from day 12 to 40. In regimen 2, Sap-10GE11-CPs/KD5, Sap20GE11-CPs/KD5, and Sap-CPs/KD5 (non-targeted control) were given at $25 \mathrm{nmol} \mathrm{Sap} / \mathrm{kg}$ from day 12 to 20 and $18 \mathrm{nmol} \mathrm{Sap} / \mathrm{kg}$ from day 24 to 40 . PBS was used as a control. During the treatment, the body weight, plasma concentrations of AFP and GP-73, 


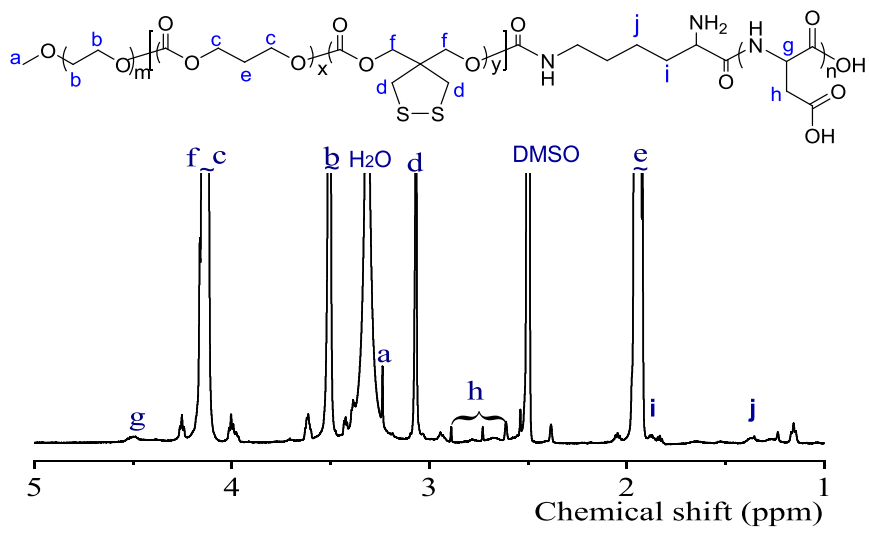

Fig. 1. ${ }^{1} \mathrm{H}$ NMR spectra (600 MHz, DMSO- $\left.d_{6}\right)$ of PEG-P(TMC-DTC)-PAsp with KD5.

and abdominal circumferences of the mice were monitored. On day 44 , one mouse of each group was sacrificed, and the heart, liver+tumor, spleen, lung, and kidney were harvested, washed, fixed, and embedded in paraffin and sliced for hematoxylin and eosin (H\&E) staining and microscope observation (Leica). The survival rates of the mice were monitored within 100 days $(n=5)$. The mice were considered dead either when the mice were dead, over $20 \%$ body weight loss, unresponsiveness, labored breathing, or obvious damage to major organs in mice within experiment period, or the abdominal circumferences of the mice was more than $100 \mathrm{~mm}$.

\subsection{Statistical analysis}

Significance among groups was assessed by one-way analysis of variance (ANOVA) with Tukey multiple comparisons test using Prism 7. Kaplan-Meier survival curves were analyzed by log-rank test for comparisons using Prism 7. ${ }^{*} p<0.05$ was considered significant, ${ }^{* *} p<0.01$ and ${ }^{* * *} p<0.001$ were highly significant, and $\left.p\right\rangle$ 0.05 meant not significant (ns).

\section{Results and discussion}

\subsection{Preparation of PEG-P(TMC-DTC)-PAsp copolymers and chimaeric polymersomes}

The aim of this study was to develop EGFR-targeted reductionresponsive chimeric polymersomes (CPs) with negatively charged inner shell for enhanced protein loading, for which PEG-P(TMCDTC)-PAsp triblock copolymers were designed and synthesized (Fig. S1A). PAsp was chosen as the negative block because it is known biodegradable and biocompatible and can be readily acquired with precise degree of polymerization (DP). To study the influence of PAsp lengths on the biophysical and protein loading properties of polymersomes, we have employed three PAsp precursors, i.e. KD5, KD10, and KD15, which have DP of 5, 10 and 15 , respectively. PEG-P(TMC-DTC)-PAsp was synthesized by activating the terminal hydroxyl group of PEG-P(TMC-DTC)-OH $\left(M_{\mathrm{n}}=5-\right.$ $14.6-2.1 \mathrm{~kg} / \mathrm{mol}$ ), which was obtained as previously reported [45], with $p$-nitrophenyl chloroformate (NPC) followed by reaction with two-fold excess of $\mathrm{KDn}(n=5,10$, or 15$)$. The ${ }^{1} \mathrm{H}$ NMR analyses demonstrated nearly quantitative NPC activation (Fig. S2) and high conjugation (88\% - 95\%) with KDn (Fig. 1, Table 1). GE11 peptide (CYHWYGYTPQNVI)-functionalized PEG-P(TMC-DTC) $\left(M_{\mathrm{n}}=7.5-14.2-2.2 \mathrm{~kg} / \mathrm{mol}\right)$ was obtained as reported previously [46] with a GE11 functionality of $95 \%$ as determined from BCA assays (Fig. S1B, Fig. S3, Table 1).
We firstly studied the assembly behaviors of PEG-P(TMC-DTC)KDn. The results showed that all three PEG-P(TMC-DTC)-KDn copolymers formed extremely small polymersomes, denoted as $\mathrm{CPs} / \mathrm{KD} 5, \mathrm{CPs} / \mathrm{KD} 10$ and $\mathrm{CPs} / \mathrm{KD} 15$, respectively, with a low polydispersity index (PDI) and good reproducibility (Fig. 2A). The hydrodynamic size of CPs decreased from 36.9, 33.5 to $32.0 \mathrm{~nm}$ (PDI 0.1) and zeta potential decreased from $-12.9,-20.0$ to $-25.6 \mathrm{mV}$ with increasing the length of KDn from 5, 10 to 15 (Fig. 2A, Table S1). Cryo-TEM showed a typical spherical vesicular structure with average sizes of $28.9 \pm 2.7,21.1 \pm 2.1$ and $15.2 \pm 1.6 \mathrm{~nm}$, respectively, and membrane thickness of 4.5 5.2 nm, for CPs/KD5, CPs/KD10 and CPs/KD15, respectively (Fig. 2B, Fig. S4). The static light scattering (SLS) measurements (Fig. 2C, Fig. S5) showed $R_{g} / R_{h}$ values in between 0.92 and 0.99 , which were close to 1.0, in accordance with a vesicular structure. These CPs had molecular weights of 2.3 $2.7 \times 10^{6} \mathrm{Da}$, which corresponds to aggregation numbers of 104.3 121.1 per polymersome (Fig. S5). Moreover, the formation of chimaeric polymersomes from block copolymers with two different lengths of hydrophilic segments was reported earlier by Eisenberg and others experimentally [47-50] and by Jiang theoretically [51]. Chimaeric polymersomes with short KDn as inner shell and PEG as outer shell were thus anticipated from PEG-P(TMC-DTC)-KDn. As comparison, the polymersomes (Ps) made of PEG-P(TMC-DTC) precursor had a hydrodynamic size of ca. $55 \mathrm{~nm}$ from DLS measurement [52] and $41.5 \mathrm{~nm}$ from Cryo TEM measurement (Fig. S4), and the membrane thickness was $6.7 \pm 0.9 \mathrm{~nm}$. The much smaller size and thinner membrane of CPs (Fig. S4) than those of Ps indicated that the introduction of short KDn block to the copolymer facilitates the formation of single layered vesicular membrane with a high curvature. To the best of our knowledge, these CPs were the smallest ever reported for lipid and polymer vesicles. Liposomes have typical sizes from hundreds of nanometers to tens of micrometers, which might be sized down to 80 to $150 \mathrm{~nm}$ by repeated extrusion [53]. The small size of CPs might be advantageous in penetrating tumors [54].

GE-11 peptide-functionalized polymersomes (GE11-CPs) were prepared by co-self-assembly of PEG-P(TMC-DTC)-KDn with GE11PEG-P(TMC-DTC) copolymers at molar ratios of 90/10, 80/20 and 70/30. The PEG linking GE11 was longer than that in PEG-P(TMCDTC)-KDn $\left(M_{\mathrm{n}}: 7500\right.$ versus $\left.5000 \mathrm{~g} / \mathrm{mol}\right)$ to ensure optimum display of GE11 at the outer surface. The sizes of GE11-CPs/KD5 increased from 41.3, 51.1 to $68.7 \mathrm{~nm}$ and zeta potential increased from $-11.4,-6.0$ to $-4.3 \mathrm{mV}$ with increasing GE11 molar contents from $10 \%, 20 \%$, to $30 \%$ (Table S1, Fig. 2D).

\subsection{Protein loading and release of chimaeric polymersomes}

The protein-loaded CPs and GE11-CPs were fabricated simply using protein containing HEPES buffer ( $\mathrm{pH} 6.8,5 \mathrm{mM}$ ) as aqueous media during self-assembly followed by removing un-encapsulated proteins through dialysis. High loading efficiencies were observed for both Cy5-labeled cytochrome C (Cy5-CC) and saporin (Sap) (Tables 2, 3, and S2), most probably driven by electrostatic interactions and hydrogen bonding of positively charged proteins with negatively charged PAsp. The protein loading contents (PLC) and efficiencies (PLE) depended on the DP of PAsp, GE11 content, and the type of protein (Table 2, 3, and S2). At a theoretical PLC of 20 wt.\% for Cy5-CC, the PLE of GE11-CPs and CPs increased from $85.4 \%, 95.6 \%$ to $100 \%$ with increasing DP of Asp-and decreasing in GE11 content, confirming that PAsp plays an important role in protein loading. For Sap, a theoretical PLC of 5 wt.\% was studied due to the high potency of this toxin [30]. The PLE decreased from $72.5 \%$, $68.2 \%, 66.1 \%$ to $59.7 \%$ with increasing GE11 contents from $0,10 \%$, $20 \%$ to $30 \%$ (Table 3). GE11-CPs and CPs exhibited much lower PLE for Sap than for CC (Table S2), which is ascribed to a comparatively lower net positive charge density of Sap as compared to CC 
Table 1

Characterizations of PEG-P(TMC-DTC)-KDn and GE11-PEG-P(TMC-DTC) copolymers.

\begin{tabular}{lllll}
\hline \multirow{2}{*}{ Entry } & Copolymers & \multicolumn{2}{l}{$M_{\mathrm{n}}(\mathrm{kg} / \mathrm{mol})$} & \multirow{2}{*}{ Functionality of KDn or GE11 } \\
\cline { 3 - 4 } \cline { 3 - 4 } & & Design & ${ }^{1} \mathrm{H}$ NMR & \\
\hline 1 & PEG-P(TMC-DTC)-KD5 & $5-(15-2)-0.72$ & $5-(14.6-2.1)-0.63$ & \\
2 & PEG-P(TMC-DTC)-KD10 & $5-(15-2)-1.29$ & $5-(14.1-2.2)-1.22$ & $92 \%$ \\
3 & PEG-P(TMC-DTC)-KD15 & $5-(15-2)-1.87$ & $5-(14.5-2.2)-1.80$ & $88 \%$ \\
4 & GE11-PEG-P(TMC-DTC) & $1.16-7.5-(15-2)$ & $1.06-7.5-(14.6-2.1)$ & $95 \%$ \\
\hline
\end{tabular}

A

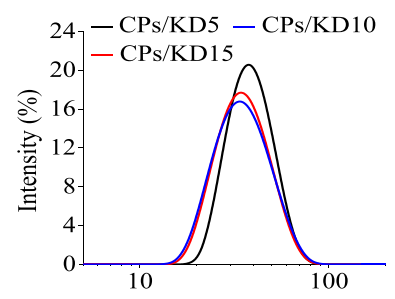

C

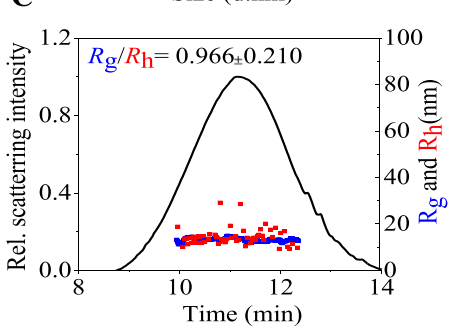

B

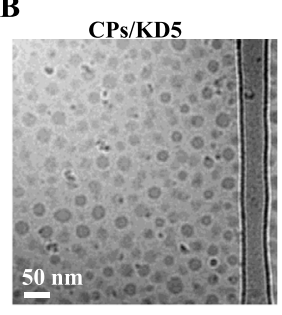

D

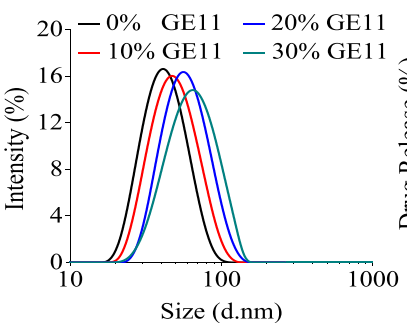

CPs/KD10

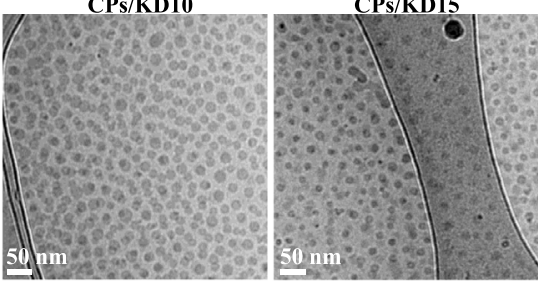

$\mathbf{E}$

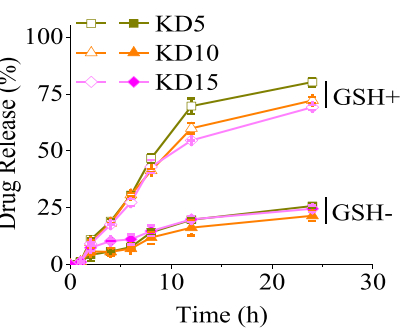

Fig. 2. The characterization of polymersomes and protein-loaded polymersomes. Size distribution (A) and Cryo-TEM images (B) of CPs/KD5, CPs/KD10 and CPs/KD15. (C) Static light scattering (SLS) measurements of $\mathrm{R}_{g}, \mathrm{R}_{\mathrm{h}}$ and molecular weight of CPs/KD5. (D) DLS profiles of GE11-CPs/KD5. (E) Cy5-CC release profiles from 10GE11-CPs/KD5, 10GE11-CPs/KD10, and 10GE11-CPs/KD15.

Table 2

Characterization of Sap-10GE11-CPs/KDn at Sap theoretical DLC of 5 wt\%.

\begin{tabular}{lllllll}
\hline Entry & KDn & DLC $^{\mathrm{a}}($ wt.\%) & DLE $^{\mathrm{a}}(\%)$ & Size $^{\mathrm{b}}(\mathrm{nm})$ & PDI $^{\mathrm{b}}$ & $\zeta^{\mathrm{b}}(\mathrm{mV})$ \\
\hline 1 & KD5 & 3.0 & 62.0 & $46 \pm 1.1$ & $0.12 \pm 0.02$ & $-9.6 \pm 0.3$ \\
2 & KD10 & 3.2 & 66.1 & $39 \pm 1.0$ & $0.09 \pm 0.01$ & $-16.7 \pm 0.2$ \\
3 & KD15 & 3.2 & 66.1 & $36 \pm 0.9$ & $0.17 \pm 0.02$ & $-22.5 \pm 0.4$ \\
\hline
\end{tabular}

a Determined by Micro BCA assay.

b Determined using Zetasizer Nano-ZS at $25^{\circ} \mathrm{C}$ in $\mathrm{PB}(10 \mathrm{mM}, \mathrm{pH}$ 7.4).

Table 3

Characterization of Sap-GE11-CPs/KD5 at Sap theoretical DLC of 5 wt\%.

\begin{tabular}{lllllll}
\hline Entry & GE11 contents & DLC $^{\mathrm{a}}(\mathrm{wt} . \%)$ & DLE $^{\mathrm{a}}(\%)$ & Size $^{\mathrm{b}}(\mathrm{nm})$ & PDI $^{\mathrm{b}}$ & $\zeta^{\mathrm{b}}(\mathrm{mV})$ \\
\hline 1 & $0 \%$ & 3.5 & 72.5 & $42 \pm 1.2$ & $0.09 \pm 0.01$ & $-10.2 \pm 0.3$ \\
2 & $10 \%$ & 3.3 & 68.2 & $47 \pm 1.8$ & $0.14 \pm 0.02$ & $-9.0 \pm 0.1$ \\
3 & $20 \%$ & 3.2 & 66.1 & $54 \pm 1.4$ & $0.17 \pm 0.02$ & $-8.2 \pm 0.2$ \\
4 & $30 \%$ & 2.9 & 59.7 & $62 \pm 2.2$ & $0.19 \pm 0.01$ & $-7.8 \pm 0.1$ \\
\hline
\end{tabular}

a Determined by Micro BCA assay.

b Determined using Zetasizer Nano-ZS at $25^{\circ} \mathrm{C}$ in PB (10 mM, pH 7.4).

[55]. The stability studies demonstrated that Sap-GE11-CPs had little change after 1 month storage at $4{ }^{\circ} \mathrm{C}$, at very low concentrations, or against 10\% serum (Fig. S6A), supporting that Sap-GE11CPs have superior stability, as for previously reported disulfidecrosslinked polymersomes [37, 46, 52].

Cy5-CC was used as a model protein to study the in vitro protein release from GE11-CPs, cellular uptake, in vivo pharmacokinetics and biodistribution, because CC has a similar isoelectric point and comparable size to Sap but much lower cell inhibition potency. The results demonstrated less than $20 \%$ protein release from 10GE11-CPs within $24 \mathrm{~h}$ in PB at pH 7.4 (Fig. 2E). Under a reduc- tive condition containing $10 \mathrm{mM} \mathrm{GSH}$, however, ca. 80\%, 72\% and 69\% Cy5-CC was released from 10GE11-CPs/KD5, 10GE11-CPs/KD10, and 10GE11-CPs/KD15, respectively, in $24 \mathrm{~h}$, corroborating their fast reduction-response [56]. TEM image of Cy5-CC-10GE11-CPs/KD5 after $10 \mathrm{mM} \mathrm{GSH}$ treatment showed irregular shape or some swollen polymersomes (Fig. S6B). It is noteworthy that the fastest protein release was observed for 10GE11-CPs/KD5 likely because short KD5 has the weakest interactions with proteins due to its lowest multivalence [57]. Hence, the inner shell of the polymersomes shall have some interactions with protein to facilitate protein loading but not too strong to retard protein release. 

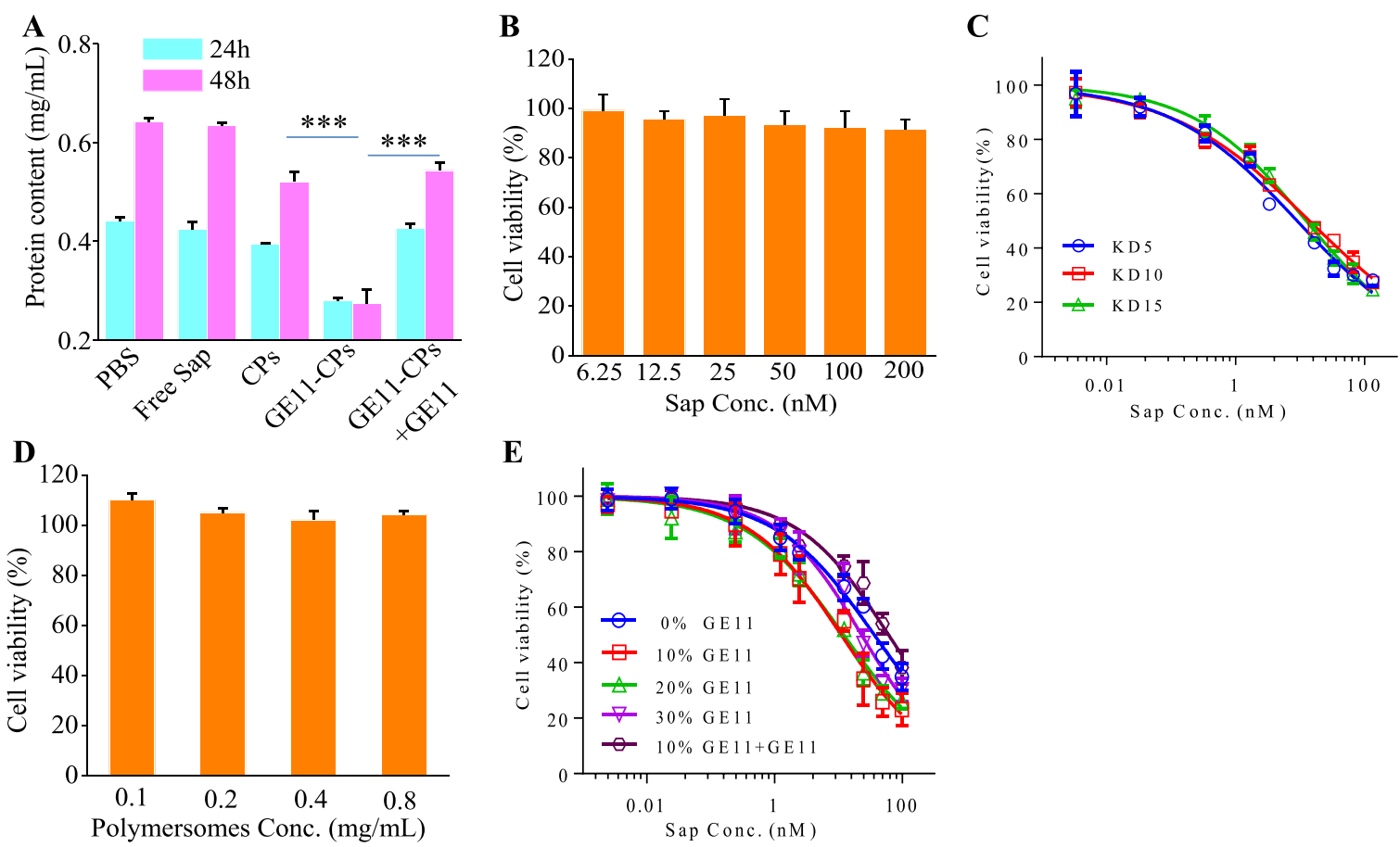

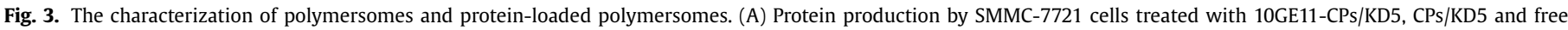

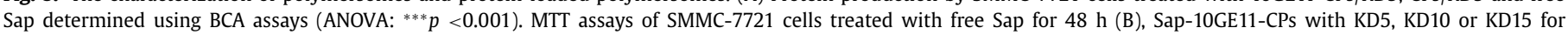

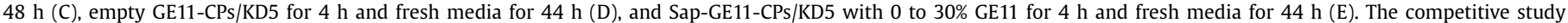
in $\mathrm{A}$ and $\mathrm{E}$ was conducted by pretreating SMMC-7721 cells with free GE11 before adding Sap formulations.

\subsection{Cell uptake and activity of Sap-GE11-CPS}

Sap is a ribosome inactivating protein [32]. To test the activity of Sap-GE11-CPs in inhibiting protein synthesis in SMMC-7721 cells, we determined the total amount of proteins in the cells and secreted to the culture media. The cells were treated with Sap10GE11-CPs/KD5 for $4 \mathrm{~h}$ and cultured for 20 or $44 \mathrm{~h}$. Free Sap, Sap-CPs/KD5, and PBS were applied as controls. The BCA assays (Fig. 3A) showed that Sap-10GE11-CPs/KD5 significantly reduced protein production compared with non-targeted Sap-CPs/KD5 and PBS $\left({ }^{* *} p\right)$, while free Sap had no effect on protein production, in accordance with its inferior entry to cells [58]. Moreover, pretreating SMMC-7721 cells with free GE11 prior to incubation with Sap10GE11-CPs/KD5 resulted in elevated protein production, to a level similar to Sap-CPs/KD5 (Fig. 3A).

MTT assays revealed that SMMC-7721 cells had over 90\% viability after $48 \mathrm{~h}$ incubation with free Sap at concentrations from 6.25 to $200 \mathrm{nM}$ (Fig. 3B). In sharp contrast, all Sap-10GE11-CPs exhibited marked inhibitory activity toward SMMC-7721 cells, with $\mathrm{IC}_{50}$ lowered to 8.9-13.8 nM depending on lengths of PAsp (Fig. 3C). Sap-10GE11-CPs/KD5 revealed the highest inhibitory activity, likely related to its faster protein release in cancer cells. The empty 10GE11-CPs/KD5 was non-cytotoxic at tested concentrations up to $800 \mu \mathrm{g} / \mathrm{mL}$ (Fig. 3D). The comparison of antitumor activities of Sap-GE11-CPs/KD5 with different GE11 contents displayed that $10 \%$ and 20\% GE11 had similarly high antitumor activity, which was two and three times better than Sap-30GE11-CPs/KD5 and non-targeted Sap-CPs/KD5, respectively (Fig. 3E), illustrating that GE11 density is of critical importance for EGFR-targetability [12]. The cytotoxicity of Sap-10GE11-CPs/KD5 was greatly reduced by pretreating SMMC7721 cells with free GE11 peptide (Fig. 3E). Sap-10GE11-CPs/KD5 was applied for subsequent studies if not otherwise stated.

The confocal images of SMMC-7721 cells after $4 \mathrm{~h}$ incubation with Cy5-CC-loaded GE11-CPs/KD5 with $10 \%$ or $20 \%$ GE11 showed homogenous and intense Cy5 fluorescence all over the cytosols (Fig. 4A, Fig. S7), indicating fast uptake and cytoplasmic protein release. In contrast, weak Cy5 fluorescence was detected in the cells treated with Cy5-CC-CPs/KD5. The intracellular Cy5 fluorescence was also greatly reduced by pretreating SMMC7721 cells with free GE11 peptide prior to adding Cy5-CC-GE11CPs/KD5 (Fig. S7). The cellular uptake study using flow cytometry revealed better uptake of Cy5-CC-GE11-CPs/KD5 with $10 \%$ GE11 or $20 \%$ GE11 than Cy5-CC-CPs/KD5 in SMMC-7721 cells (Fig. 4B). In comparison, less enhancement in uptake was observed for Cy5CC-GE11-CPs/KD5 in EGFR negative K562 cells (Fig. S8). These results confirm that GE11-CPs/KD5 possesses a strong selectivity toward SMMC-7721 cells and enters the cell via EGFR-mediated endocytosis.

\subsection{The pharmacokinetics and HCC-targetability of GE11-CPs/KDn}

The pharmacokinetic studies in healthy Balb/c mice using Cy5-CC as a model protein demonstrated that CPs/KD5, 10GE11CPs/KD5, 10GE11-CPs/KD10, 10GE11-CPs/KD15, and 20GE11CPs/KD5 all followed a two-compartment model with a slow elimination phase and markedly extended circulation time over free Cy5-CC (Fig. 5A). The elimination half-life $\left(\mathrm{t}_{1 / 2, \beta}\right)$ of Cy5-CC10GE11-CPs/KDn increased from 3.1, 3.4 to $4.0 \mathrm{~h}$ with decreasing DP of PAsp from 15, 10 to 5 (Fig. 5A), which is possibly due to different sizes (37.1, 40.6, and $43.8 \mathrm{~nm}$ ). It should further be noted that both 10GE11-CPs/KD5 and 20GE11-CPs/KD5 had longer circulation time than $\mathrm{CPs} / \mathrm{KD} 5$, indicating that GE11 has no detrimental effect to the pharmacokinetics. Moreover, over 10 times improvement in area under the curve (AUC) was observed for all polymersomal formulations compared with free protein (Fig. 5A).

The in vivo imaging in SMMC-7721 subcutaneous tumorbearing mice demonstrated faster and higher tumor accumulation and retention of Cy5-CC-GE11-CPs/KD5 than Cy5-CC-CPs/KD5 over $10 \mathrm{~h}$ post-injection (Fig. 5B). The quantification of $\mathrm{Cy} 5-\mathrm{CC}$ in tumors and healthy organs at $10 \mathrm{~h}$ post-injection revealed an ele- 


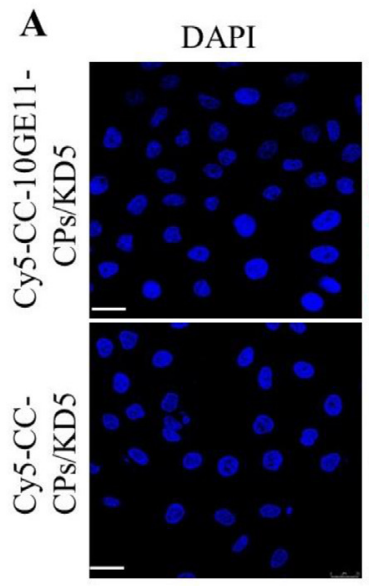

B

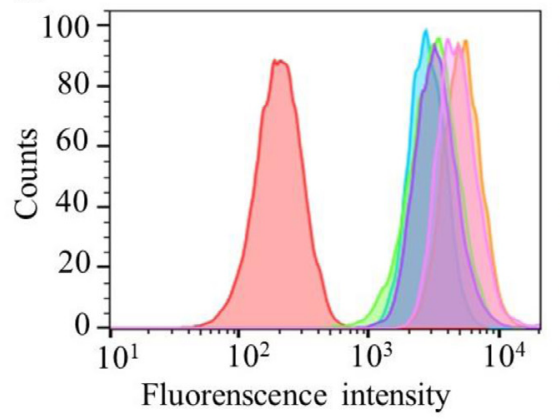

Cy5-CC
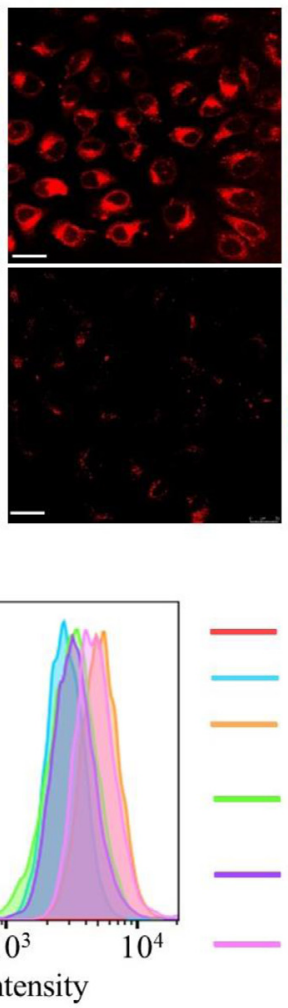

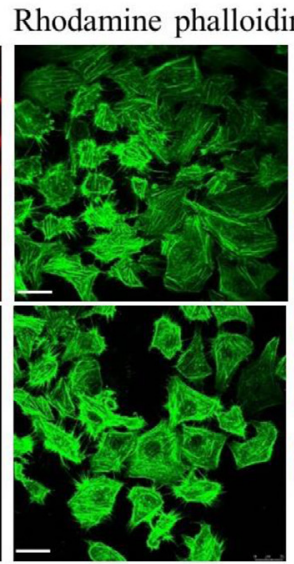

\section{F}

219

PBS

Cy5-CC-CPs/KD5

Cy5-CC-10GE11

$-\mathrm{CPs} / \mathrm{KD} 5$

Cy5-CC-10GE11

$-\mathrm{CPs} / \mathrm{KD} 5+\mathrm{GE} 11$

Cy5-CC-20GE11

$-\mathrm{CPs} / \mathrm{KD} 5$

Cy5-CC-20GE11

$-\mathrm{CPs} / \mathrm{KD} 5+\mathrm{GE} 11$

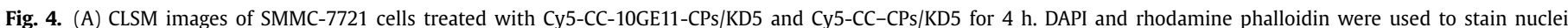

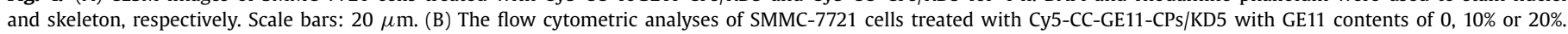
For inhibition experiment, the cells were pretreated with GE11 peptide before addition of polymersome formulations.

vated tumor accumulation of 7.5\%ID/g for Cy5-CC-GE11-CPs/KD5, which was 3-fold higher than the non-targeted Cy5-CC-CPs/KD5 (Fig. 5C). There were no significant differences in Cy5-CC accumulation in the healthy organs between Cy5-CC-GE11-CPs/KD5 and Cy5-CC-CPs/KD5.

We further established orthotopic HCC tumor model by inoculating SMMC-7721 cells $\left(3 \times 10^{6}\right)$ into the right liver lobes of the nude mice. The progression of tumor was monitored by measuring the plasma concentration of alpha-fetoprotein (AFP) and Golgi protein 73 (GP73), ascites development and excised livers at certain time points. AFP is a liver tumor marker used in clinical practice and in healthy adults AFP is less than $40 \mu \mathrm{g} / \mathrm{L}$. Although AFP is related with tumor size, the difference between individuals is large [59]. GP73 protein is a more sensitive biomarker of liver cancer than AFP. The combination of AFP and GP73 could provide more accurate diagnosis of liver tumors [60]. The plasma levels of AFP and GP73 indeed increased gradually in 10 days post-inoculation of SMMC-7721 cells and more significantly afterwards (Fig. S9A,B). The visual inspection from the excised livers accordingly displayed the clear presence and progressively increased tumors on day 14 , 18, 30, and 44 (Fig. S9C). The tumors spread not only within liver lobes, but also to major organs and intestines. Severe ascites was discerned from day 30 on. The quantitative biodistribution studies in SMMC-7721 orthotopic tumor-bearing mice showed tumor accumulation of $8.7 \%$ and $2.9 \%$ ID/g for GE11-Cy5-CC-CPs/KD5 and Cy5CC-CPs/KD5, respectively, at $10 \mathrm{~h}$ post-injection (Fig. 5D), which was in good correlation with the results from the subcutaneous model. It is evident, therefore, that GE11-CPs/KD5 can actively target to HCC tumor in vivo.

\subsection{Therapeutic efficacy of Sap-GE11-CPS to orthotopic HCC tumor model}

EGFR is overexpressed on a majority of HCC tumor patients [38]. The clinical results confirmed the efficacy of EGFR antagonists e.g. gefitinib in liver cancer patients [61], and EGFR-TKI antagonist, erlotinib, in advanced HCC patients [62]. GE11 peptides screened from phage display showed a high affinity for EGFR [41]. The results from different groups showed that GE11functionalized nanoformulations enhanced the therapy for diverse EGFR-overexpressed tumors such as breast, prostate and ovarian cancers [42-44,46]. Unlike EGFR antibody and EGF protein, GE11 would not cause activation of EGFR signaling pathway [38,63].

The treatment of orthotopic HCC tumor-bearing mice was initiated by intravenously administering Sap-10GE11-CPs/KD5, Sap20GE11-CPs/KD5 or PBS starting from 12 days post-inoculation of SMMC-7721 cells, when the plasma concentrations of AFP and GP73 reached 26.9 and $25.9 \mathrm{ng} / \mathrm{mL}$, respectively. The body weight, AFP and GP73 concentrations, mouse abdominal circumference, and survival rates were monitored. PBS group showed rapid increase in body weight and abdominal circumference due to malignant tumor invasion and occurrence of hepatic ascites (Fig. 6A,B). Notably, AFP and GP73 concentrations increased from 26.9 to $111.4 \mathrm{ng} / \mathrm{mL}$ and from 25.9 to $153.2 \mathrm{ng} / \mathrm{mL}$, respectively, from day 12 to 33 (Fig. 6C,D,E). For humanitarian reasons, the mice were regarded dead when their abdominal circumferences exceeded $100 \mathrm{~mm}$. The median survival time (MST) of PBS group was 34 days (Fig. 6F). In contrast, the mice treated with Sap-10GE11CPs/KD5 or Sap-20GE11-CPs/KD5 at $12.5 \mathrm{nmol} / \mathrm{kg}$ every 4 days for 
a total of 8 injections (regimen 1) displayed constant body weights (Fig. 6A). The increase of plasma AFP and GP73 levels as well as abdominal circumference was obviously retarded compared with PBS control (Fig. 6C,D,E). In accordance, Sap-10GE11-CPs/KD5 and Sap-20GE11-CPs/KD5 significantly prolonged the MST of mice to 66 and 57 d, respectively (Fig. 6F). 10\% GE11 appeared to perform somewhat better than $20 \%$ GE11.

The treatment was further performed at an escalated dose scheme with 3 injections at $25 \mathrm{nmol} / \mathrm{kg}$ followed by 5 injections at $18 \mathrm{nmol} / \mathrm{kg}$ (regimen 2). Sap-CPs/KD5 under regimen 2 caused little change in body weights (Fig. 6A) and retarded increase of plasma AFP and GP73 levels as well as abdominal circumference (Fig. 6C,D,E), similar to Sap-GE11-CPs/KD5 under regimen 1. However, in contrast to Sap-10GE11-CPs/KD5 and Sap-20GE11-CPs/KD5 under regimen 1, Sap-CPs/KD5 under regimen 2 gave little survival benefits (MST $=42$ days), possibly due to their low tumor uptake. Interestingly, both Sap-10GE11-CPs/KD5 and Sap-20GE11CPs/KD5 under regimen 2 showed highly efficacious treatment of orthotopic HCC tumor-bearing mice, in which little increase of AFP and GP73 concentrations and abdominal circumference was discerned (Fig. 6C,D,E). The excised livers displayed only small tumor for Sap-20GE11-CPs/KD5 treated mouse and no tumors for Sap-10GE11-CPs/KD5 treated one under regimen 2 (Fig. 6B). The weights of livers from mice of Sap-10GE11-CPs/KD5 under regimen 2 and regimen 1 ( 0.96 and $1.09 \mathrm{~g}$ ) were obviously lower than SapCPs/KD5 and PBS groups (1.28 and $1.53 \mathrm{~g}$ ). As a result, Sap-10GE11CPs/KD5 and Sap-20GE11-CPs/KD5 under regimen 2 brought about significant survival benefits with MST of 99 and 91 d (Fig. 6F), which were about 3 times that of PBS control. In addition, the investigation on the protein penetration of Cy5-CC loaded GE11CPs/KD5 group into the subcutaneous liver tumors displayed much higher and more spread fluorescence in the tumor compared to the CPs/KD5 group (Fig. S10). These results highlight that GE11CPs/KD5 mediate efficient and specific protein therapy for HCC in mice. In accordance, H\&E staining showed that four Sap-GE11$\mathrm{CPs} / \mathrm{KD} 5$ groups caused no significant side-effects on the major or- gans and normal liver tissues of mice (Fig. S11), due to the specificity of GE11 to EGFR on HCC tumor cells.

\section{Conclusion}

We have demonstrated that GE11 peptide-installed chimaeric polymersomes (GE11-CPs) mediate safe and high-efficiency EGFRtargeted protein therapy of orthotopic SMMC-7721 HCC-bearing nude mice. This is a first report on targeted delivery of protein toxin to HCC. Notably, unlike previously reported protein delivery systems (e.g. polymersomes based on PEG-P(TMC-DTC)-PEI) that contain partially toxic or nondegradable components, GE11-CPs are fully made of PEG, polycarbonate and peptides. In addition to favorable safety, saporin-loaded GE11-CPs display appealing advantages such as exceptionally small size (36 - $46 \mathrm{~nm}$ ), stable saporin loading, high specificity and enhanced internalization by EGFR+ HCC cells, and GSH-triggered saporin release. As a result, GE11-CPs markedly increase the selectivity and antitumor activity of saporin with an $\mathrm{IC}_{50}$ of $11 \mathrm{nM}$ toward SMMC-7721 cells, and prolong the blood circulation and increase the tumor accumulation of saporin, leading to significantly improved anti-HCC effect and survival rates. GE11-CPs appear to be a safe and potent vehicle for targeted protein therapy of EGFR positive HCC.

\section{Declaration of Competing Interest}

The authors declare that they have no known competing financial interests or personal relationships that could have appeared to influence the work reported in this paper.

\section{Acknowledgement}

This work is supported by research grants from the National Natural Science Foundation of China (NSFC 51773146, 51861145310, 51561135010, 51633005) and Post Graduate Research \& Practice Innovation Program of Jiangsu Province (KYCX19_1901).

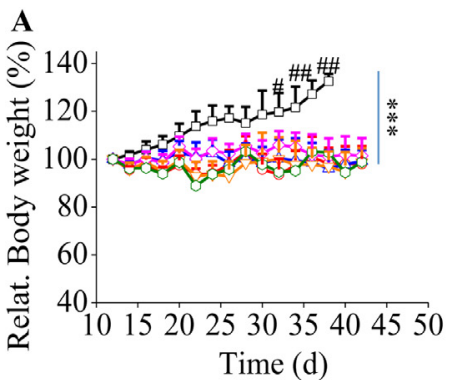

C

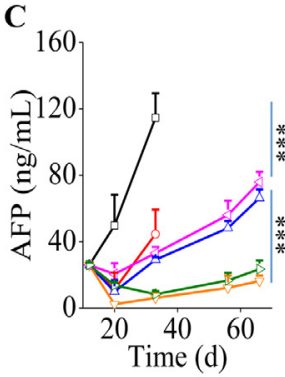

D 200

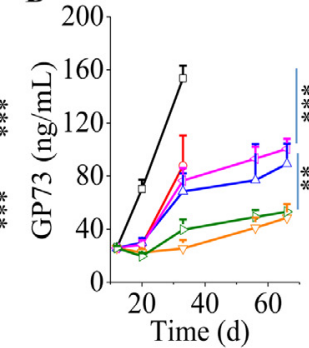

B

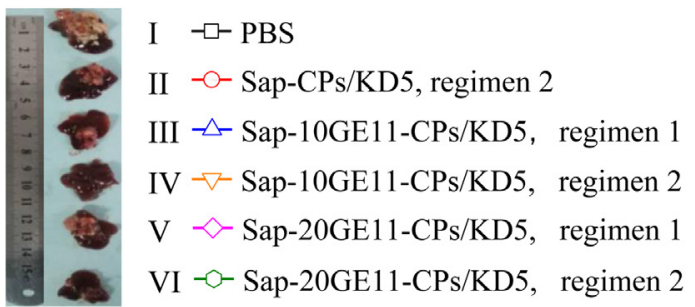

E

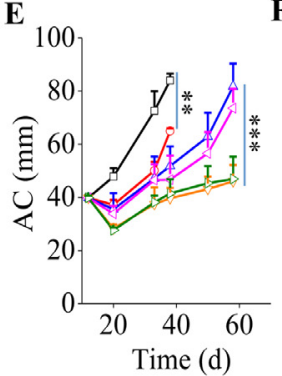

F

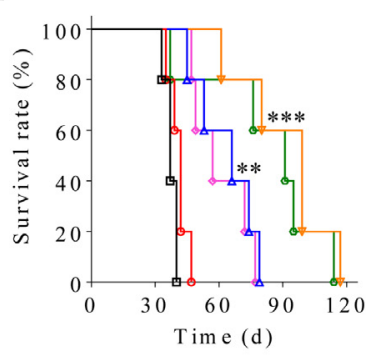

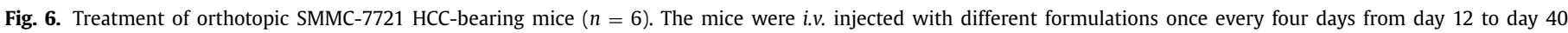

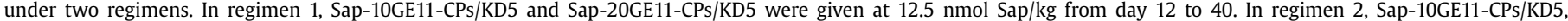

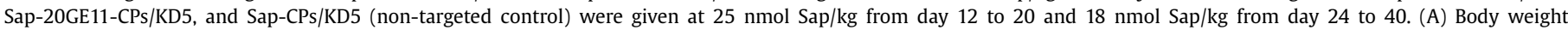

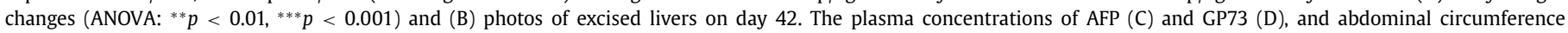

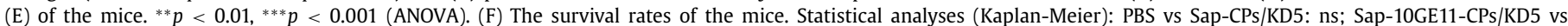

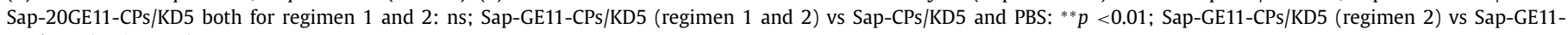
CPs/KD5 (regimen 1 ): ${ }^{*} p<0.1$. 


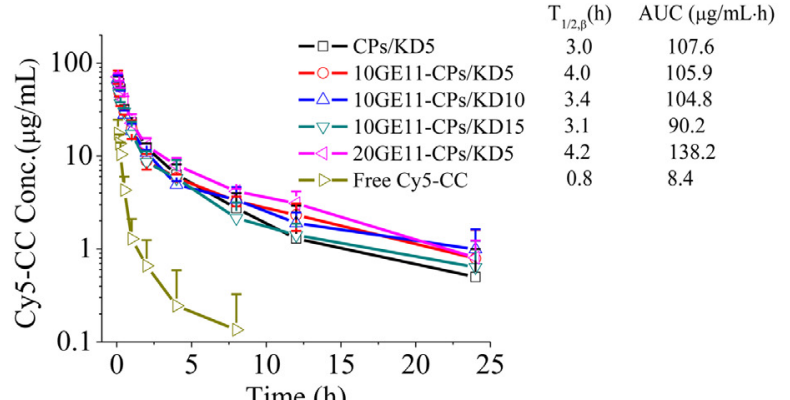

B

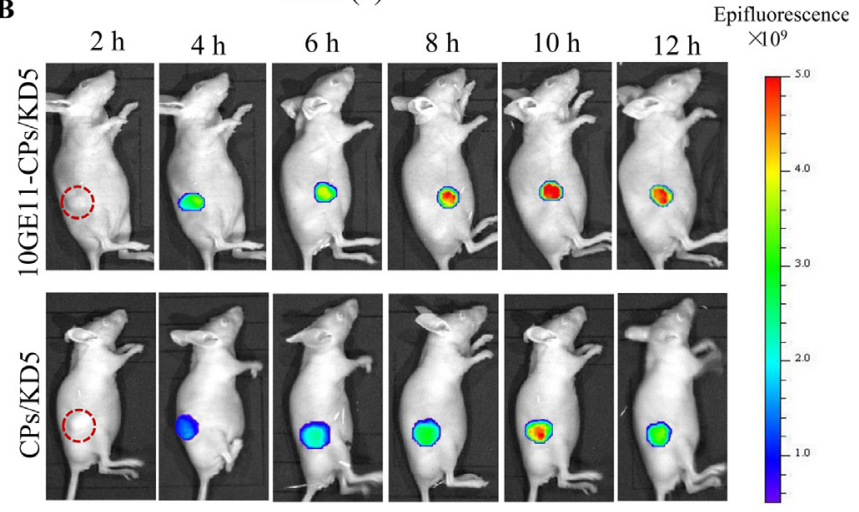

C
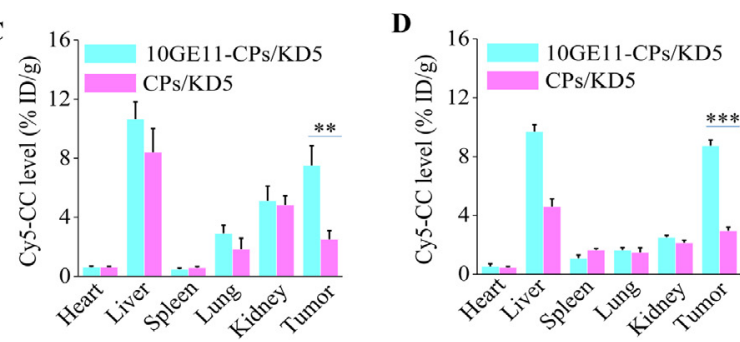

Fig. 5. The In vivo pharmacokinetics of Cy5-CC delivered by 10GE11-CPs/KDn with different PAsp, CPs/KDn and free Cy5-CC in mice $(n=3)(A)$. The in vivo imaging (B), and quantitative biodistribution of Cy5-CC in major organs and tumors of the mice bearing subcutaneous (C) or orthotopic tumors (D) at $10 \mathrm{~h}$ post-injection of Cy5-CC-10GE11-CPs/KD5 and Cy5-CC-CPs/KD5. Dosage: $0.72 \mu \mathrm{mol}$ Cy5 equiv./kg. ${ }^{* *} p$ $<0.01$ and ${ }^{* * *} p<0.001$ (ANOVA).

\section{Supplementary materials}

Supplementary material associated with this article can be found, in the online version, at doi:10.1016/j.actbio.2020.06.020.

\section{References}

[1] H.B. El-Serag, Epidemiology of hepatocellular carcinoma, The Liver 59 (2020) $758-772$

[2] P.R. Galle, A. Forner, J.M. Llovet, V. Mazzaferro, F. Piscaglia, J.-L. Raoul, P. Schirmacher, V. Vilgrain., EASL clinical practice guidelines: management of hepatocellular carcinoma, J. Hepatol. 69 (2018) 182-236.

[3] A.-.L. Cheng, Y.-.K. Kang, Z. Chen, C.-.J. Tsao, S. Qin, J.S. Kim, R. Luo, J. Feng, S. Ye, T.-.S. Yang, J. Xu, Y. Sun, H. Liang, J. Liu, J. Wang, W.Y. Tak, H. Pan, K. Burock, J. Zou, D. Voliotis, Z. Guan, Efficacy and safety of sorafenib in patients in the Asia-Pacific region with advanced hepatocellular carcinoma: a phase III randomised, double-blind, placebo-controlled trial, Lancet Oncol. 10 (2009) 25-34.

[4] A.B. El-Khoueiry, B. Sangro, T. Yau, T.S. Crocenzi, M. Kudo, C. Hsu, T.-.Y. Kim, S.-.P. Choo, J. Trojan, T.H. Welling, T. Meyer, Y.-.K. Kang, W. Yeo, A. Chopra, J. Anderson, C. dela Cruz, L. Lang, J. Neely, H. Tang, H.B. Dastani, I. Melero, Nivolumab in patients with advanced hepatocellular carcinoma (CheckMate 040): an open-label, non-comparative, phase $1 / 2$ dose escalation and expansion trial, Lancet 389 (2017) 2492-2502.

[5] J. Lu, J. Wang, D. Ling, Surface Engineering of Nanoparticles for Targeted Delivery to Hepatocellular Carcinoma, Small 14 (2018) 1702037.

[6] N.K. Mohamed, M.A. Hamad, M.Z. Hafez, K.L. Wooley, M. Elsabahy, Nanomedicine in management of hepatocellular carcinoma: challenges and opportunities, Int. J. Cancer 140 (2017) 1475-1484.
[7] X. Zhang, H.L.H. Ng, A. Lu, C. Lin, L. Zhou, G. Lin, Y. Zhang, Z. Yang, H. Zhang, Drug delivery system targeting advanced hepatocellular carcinoma: current and future, Nanomedicine 12 (2016) 853-869.

[8] Y.H. Wei, X.L. Gu, L. Cheng, F.H. Meng, G. Storm, Z.Y. Zhong, Low-toxicity transferrin-guided polymersomal doxorubicin for potent chemotherapy of orthotopic hepatocellular carcinoma in vivo, Acta Biomater 92 (2019) 196-204.

[9] X. Tang, L. Chen, A. Li, S. Cai, Y. Zhang, X. Liu, Z. Jiang, X. Liu, Y. Liang, D. Ma, Anti-GPC3 antibody-modified sorafenib-loaded nanoparticles significantly inhibited HepG2 hepatocellular carcinoma, Drug Deliv. 25 (2018) 1484-1494.

[10] Z. Xie, P.F. Choong, L.F. Poon, J. Zhou, J. Khng, V.J. Jasinghe, S. Palaniyandi, C.S. Chen, Inhibition of CD44 expression in hepatocellular carcinoma cells enhances apoptosis, chemosensitivity, and reduces tumorigenesis and invasion, Cancer Chemother. Pharmacol. 62 (2008) 949-957.

[11] J. Gao, Y. Xia, H. Chen, Y. Yu, J. Song, W. Li, W. Qian, H. Wang, J. Dai, Y. Guo, Polymer-lipid hybrid nanoparticles conjugated with anti-EGF receptor antibody for targeted drug delivery to hepatocellular carcinoma, Nanomedicine 9 (2014) 279-293.

[12] Y. Fang, W.J. Yang, L. Cheng, H.F. Meng, J. Zhang, Y.Z. Zhong, EGFR-targeted multifunctional polymersomal doxorubicin induces selective and potent suppression of orthotopic human liver cancer in vivo, Acta Biomater 64 (2017) 323-333.

[13] B. Jiang, R. Zhang, J. Zhang, Y. Hou, X. Chen, M. Zhou, X. Tian, C. Hao, K. Fan, X. Yan, GRP78-targeted ferritin nanocaged ultra-high dose of doxorubicin for hepatocellular carcinoma therapy, Theranostics 9 (2019) 2167-2182.

[14] D. Zhu, W. Tao, H. Zhang, G. Liu, T. Wang, L. Zhang, X. Zeng, L. Mei, Doc etaxel (DTX)-loaded polydopamine-modified TPGS-PLA nanoparticles as a targeted drug delivery system for the treatment of liver cancer, Acta Biomater 30 (2016) 144-154

[15] S.S. Usmani, G. Bedi, J.S. Samuel, S. Singh, S. Kalra, P. Kumar, A.A. Ahuja, M. Sharma, A. Gautam, G.P. Raghava, THPdb: database of FDA-approved peptide and protein therapeutics, PLoS ONE 12 (2017) e0181748.

[16] B. Leader, Q.J. Baca, D.E. Golan, Protein therapeutics: a summary and pharmacological classification, Nat. Rev. Drug Discov. 7 (2008) 21-39.

[17] P.E. Saw, E.W. Song, siRNA therapeutics: a clinical reality, Sci. China: Life Sci. 62 (2019) 1-16.

[18] L. Cheng, L. Yang, F.H. Meng, Z.Y. Zhong, Protein nanotherapeutics as an emerging modality for cancer therapy, Adv. Healthc. Mater. 7 (2018) e1800685.

[19] J.A. Kulkarni, D. Witzigmann, S. Chen, P.R. Cullis, R. van der Meel, Lipid nanoparticle technology for clinical translation of siRNA therapeutics, Acc. Chem. Res. 52 (2019) 2435-2444.

[20] K.-.W. Huang, Y.-.T. Lai, G.-.J. Chern, S.-.F. Huang, C.-.L. Tsai, Y.-.C. Sung, C.-.C. Chiang, P.-.B. Hwang, T.-.L. Ho, R.-.L. Huang, Galactose derivative-modified nanoparticles for efficient siRNA delivery to hepatocellular carcinoma, Biomacromolecules 19 (2018) 2330-2339.

[21] Y. Xia, C. Wang, T. Xu, Y. Li, M. Guo, Z. Lin, M. Zhao, B. Zhu, Targeted delivery of HES5-siRNA with novel polypeptide-modified nanoparticles for hepatocellular carcinoma therapy, RSC Adv. 8 (2018) 1917-1926.

[22] Z. Ye, W.-.R. Wu, Y.-.F. Qin, J. Hu, C. Liu, P.H. Seeberger, J. Yin, An integrated therapeutic delivery system for enhanced treatment of hepatocellular carcinoma, Adv. Funct. Mater. 28 (2018) 1706600.

[23] Y. Ye, J. Yu, D. Wen, A.R. Kahkoska, Z. Gu, Polymeric microneedles for transdermal protein delivery, Adv. Drug Deliv. Rev. 127 (2018) 106-118.

[24] M. Liu, S. Shen, D. Wen, M. Li, T. Li, X. Chen, Z. Gu, R. Mo, Hierarchical nanoassemblies-assisted combinational delivery of cytotoxic protein and antibiotic for cancer treatment, Nano Lett 18 (2018) 2294-2303.

[25] D. Li, C.F. van Nostrum, E. Mastrobattista, T. Vermonden, W.E. Hennink, Nanogels for intracellular delivery of biotherapeutics, J. Controlled Release 259 (2017) 16-28,

[26] X. Si, S. Ma, Y. Xu, D. Zhang, N. Shen, H. Yu, Y. Zhang, W. Song, Z. Tang, $X$. Chen, Hypoxia-sensitive supramolecular nanogels for the cytosolic delivery of ribonuclease A as a breast cancer therapeutic, J. Controlled Release 320 (2020) 83-95.

[27] Z. Cheng, S. Hong, M.-.D. Liu, W.-.Y. Yu, M.-.K. Zhang, L. Zhang, X. Zeng, $\mathrm{pH}$-sensitive MOF integrated with glucose oxidase for glucose-responsive insulin delivery, J. Controlled Release 320 (2020) 159-167.

28] D. Flavell, D. Boehm, A. Noss, S. Warnes, S. Flavell, Therapy of human Tcell acute lymphoblastic leukaemia with a combination of anti-CD7 and anti-CD38-SAPORIN immunotoxins is significantly better than therapy with each individual immunotoxin, Br. J. Cancer 84 (2001) 571-578.

[29] L. Polito, D. Mercatelli, M. Bortolotti, S. Maiello, A. Djemil, M.G. Battelli, A. Bolognesi, Two saporin-containing immunotoxins specific for CD20 and CD22 show different behavior in killing lymphoma cells, Toxins (Basel) 9 (2017) 182 http://doi, doi:10.3390/toxins9060182.

[30] E. Capone, F. Giansanti, S. Ponziani, A. Lamolinara, M. Iezzi, A. Cimini, F. Angelucci, R.L. Sorda, V.D. Laurenzi, P.G. Natali, R. Ippoliti, S. Iacobelli, a.G. Sala, EV20-Sap, a novel anti-HER-3 antibody-drug conjugate, displays promising antitumor activity in melanoma, Oncotarget 8 (2017) 95412-95424.

[31] D. Flavell, S. Flavell, D. Boehm, L. Emery, A. Noss, N. Ling, P. Richardson, D. Hardie, D. Wright, Preclinical studies with the anti-CD19-saporin immunotoxin BU12-SAPORIN for the treatment of human-B-cell tumours, Br. J. Cancer 72 (1995) 1373-1379.

[32] G. Bergamaschi, V. Perfetti, L. Tonon, A. Novella, C. Lucotti, M. Danova, M.J. Glennie, G. Merlini, M. Cazzola, Saporin, a ribosome -inactivating protein used to prepare immunotoxins, induces cell death via apoptosis, Br. J. Haematol 93 (1996) 789-794. 
[33] F. Giansanti, D.J. Flavell, F. Angelucci, M.S. Fabbrini, R. Ippoliti, Strategies to improve the clinical utility of saporin-based targeted toxins, Toxins (Basel) 10 (2018) 82 https://doi.org/10.3390/toxins10020082.

[34] A.M. Asrorov, Z. Gu, K.A. Min, M.C. Shin, Y. Huang, Advances on tumor-targeting delivery of cytotoxic proteins, ACS Pharmacol. Transl. Sci. 3 (2020) 107-118.

[35] J. Chen, H. He, C. Deng, L.C. Yin, Z.Y. Zhong, Saporin-loaded CD44 and EGFR dual-targeted nanogels for potent inhibition of metastatic breast cancer in vivo, Int. J. Pharm. 560 (2019) 57-64.

[36] L. Martinez Jothar, N. Beztsinna, C.F. van Nostrum, W.E. Hennink, S. Oliveira, Selective cytotoxicity to HER2 positive breast cancer cells by saporin-loaded nanobody-targeted polymeric nanoparticles in combination with photochemical internalization, Mol.Pharmaceut. 16 (2019) 1633-1647.

[37] Y. Jiang, J. Zhang, F.H. Meng, Z.Y. Zhong, Apolipoprotein E peptide-directed chimeric polymersomes mediate an ultrahighefficiency targeted protein therapy for glioblastoma, ACS Nano 12 (2018) 11070-11079.

[38] A.F. Buckley, L.J. Burgart, V. Sahai, S. Kakar, Epidermal growth factor receptor expression and gene copy number in conventional hepatocellular carcinoma, Am. J. Clin. Pathol. 129 (2008) 245-251.

[39] S. Goodison, V. Urquidi, D. Tarin, CD44 cell adhesion molecules, J. Clin. Pathol.: Mol. Pa. 52 (1999) 189-196.

[40] K. Endo, T. Terada, Protein expression of CD44 (standard and variant isoforms) in hepatocellular carcinoma: relationships with tumor grade, clinicopathologic parameters, p53 expression, and patient survival, J. Hepatol 32 (2000) 78-84.

[41] Z. Li, R. Zhao, X. Wu, Y. Sun, M. Yao, J. Li, Y, Xu, J. Gu, Identification and characterization of a novel peptide ligand of epidermal growth factor receptor for targeted delivery of therapeutics, FASEB J 19 (2005) 1978-1985.

[42] D. Hu, O. Mezghrani, L. Zhang, Y. Chen, X. Ke, T. Ci, GE11 peptide modified and reduction-responsive hyaluronic acid-based nanoparticles induced higher efficacy of doxorubicin for breast carcinoma therapy, Int. J. Nanomed. 11 (2016) $5125-5147$.

[43] J. Pi, J. Jiang, H. Cai, F. Yang, H. Jin, P. Yang, J. Cai, Z.W. Chen, GE11 peptide conjugated selenium nanoparticles for EGFR targeted oridonin delivery to achieve enhanced anticancer efficacy by inhibiting EGFR-mediated PI3K/AKT and Ras/Raf/MEK/ERK pathways, Drug Deliv. 24 (2017) 1549-1564.

[44] J. Yan, Y. Wang, Y. Jia, S. Liu, C. Tian, W. Pan, X. Liu, H. Wang, Co-delivery of docetaxel and curcumin prodrug via dual-targeted nanoparticles with synergistic antitumor activity against prostate cancer, Biomed. Pharmacother. 88 (2017) 374-383.

[45] W.J. Yang, Y.F. Xia, Y. Fang, F.H. Meng, J. Zhang, R. Cheng, C. Deng, Z.Y. Zhong, Selective cell penetrating peptide-functionalized polymersomes mediate efficient and targeted delivery of methotrexate disodium to human lung cancer in vivo, Adv. Healthc. Mater. 7 (2018) 1701135.

[46] Y. Zou, Y.F. Xia, F.H. Meng, J. Zhang, Z.Y. Zhong, GE11-directed functional polymersomal doxorubicin as an advanced alternative to clinical liposomal formulation for ovarian cancer treatment, Mol. Pharmaceut. 15 (2018) 3664-3671.

[47] L. Luo, A. Eisenberg, One-step preparation of block copolymer vesicles with preferentially segregated acidic and basic corona chains, Angew. Chem., Int. Ed. 41 (2002) 1001-1004.

[48] L. Luo, A. Eisenberg, Thermodynamic stabilization mechanism of block copolymer vesicles, J. Am. Chem. Soc. 123 (2001) 1012-1013.

[49] G.J. Liu, S.B. Ma, S.K. Li, R. Cheng, F.H. Meng, H.Y. Liu, Z.Y. Zhong, The highly efficient delivery of exogenous proteins into cells mediated by biodegradable chimaeric polymersomes, Biomaterials 31 (2010) 7575-7585.
[50] S.X. Junjie Li, Yixuan Xu, Shuai Zuo, Zengshi Zha, Wendong Ke, Chuanxin He, Zhishen Ge, Smart asymmetric vesicles with triggered availability of inner cell-penetrating shells for specific intracellular drug delivery, Acs Appl. Mater. Inter. 9 (2017) 17727-17735.

[51] J. Cui, Y. Han, W. Jiang, Asymmetric vesicle constructed by $A B / C B$ diblock copolymer mixture and its behavior: a monte carlo study, Langmuir 30 (2014) 9219-9227.

[52] W.X. Gu, J. An, H. Meng, N. Yu, Y.N. Zhong, F.H. Meng, Y. Xu, J.J.L.M. Cornelissen, Z.Y. Zhong, CD44-specific a6 short peptide boosts targetability and anticancer efficacy of polymersomal epirubicin to orthotopic human multiple myeloma, Adv. Mater. 31 (2019) 1904742.

[53] E. Rideau, R. Dimova, P. Schwille, F.R. Wurm, K. Landfester, Liposomes and polymersomes: a comparative review towards cell mimicking, Chem. Soc. Rev. 47 (2018) 8572-8610.

[54] C. Bi, X.Q. Miao, S.F. Chow, W.J. Wu, R. Yan, Y.H. Liao, A.H.-L. Chow, Y. Zheng, Particle size effect of curcumin nanosuspensions on cytotoxicity, cellular internalization, in vivo pharmacokinetics and biodistribution, Nanomed.-Nanotechnol. Biol. Med. 13 (2017) 943-953.

[55] Y. Lee, T. Ishii, H. Cabral, H.J. Kim, J.H. Seo, N. Nishiyama, H. Oshima, K. Osada, K. Kataoka, Charge-conversional polyionic complex micelles-efficient nanocarriers for protein delivery into cytoplasm, Angew. Chem., Int. Ed. 48 (2009) 5309-5312.

[56] W.J. Yang, Y.H. Wei, L. Yang, J. Zhang, Z.Y. Zhong, G. Storm, F.H. Meng Granzyme B-loaded, cell-selective penetrating and reduction-responsive polymersomes effectively inhibit progression of orthotopic human lung tumor in vivo, J. Controlled Release 290 (2018) 141-149.

[57] C. Fasting, C.A. Schalley, M. Weber, O. Seitz, S. Hecht, B. Koksch, J. Dernedde, C. Graf, E.W. Knapp, R. Haag, Multivalency as a chemical organization and action principle, Angew. Chem. Int. Ed. Engl. 51 (2012) 10472-10498.

[58] M. Wang, K. Alberti, S. Sun, C.L. Arellano, Q. X, Combinatorially Designed Lipidlike Nanoparticles for Intracellular Delivery of Cytotoxic Protein for Cancer Therapy, Angew. Chem., Int. Ed. 53 (2014) 2893-2898.

[59] N. Tayob, A.S. Lok, K.-.A. Do, Z. Feng, Improved detection of hepatocellular carcinoma by using a longitudinal alpha-fetoprotein screening algorithm, Clin. Gastroenterol. Hepatol. 14 (2016) 469-475.

[60] J.A. Marrero, P.R. Romano, O. Nikolaeva, L. Steel, A. Mehta, C.J. Fimmel, M.A. Comunale, A. D’Amelio, A.S. Lok, T.M. Block, GP73, a resident Golgi glycoprotein, is a novel serum marker for hepatocellular carcinoma, J. Hepatol 43 (2005) 1007-1012.

[61] M. Hopfner, A.P. Sutter, A. Huether, D. Schuppan, M. Zeitz, H. Scherubl, Targeting the epidermal growth factor receptor by gefitinib for treatment of hepatocellular carcinoma, J. Hepatol. 41 (2004) 1008-1016.

[62] P.A. Philip, M.R. Mahoney, C. Allmer, J. Thomas, H.C. Pitot, G. Kim, R.C. Donehower, T. Fitch, J. Picus, C. Erlichman, Phase II study of Erlotinib (OSI-774) in patients with advanced hepatocellular cancer, J. Clin. Oncol. 23 (2005) 6657-6663.

[63] F.M. Mickler, L. Mockl, N. Ruthardt, M. Ogris, E. Wagner, C. Brauchle, Tuning nanoparticle uptake: live-cell imaging reveals two distinct endocytosis mechanisms mediated by natural and artificial EGFR targeting ligand, Nano Lett 12 (2012) 3417-3423. 